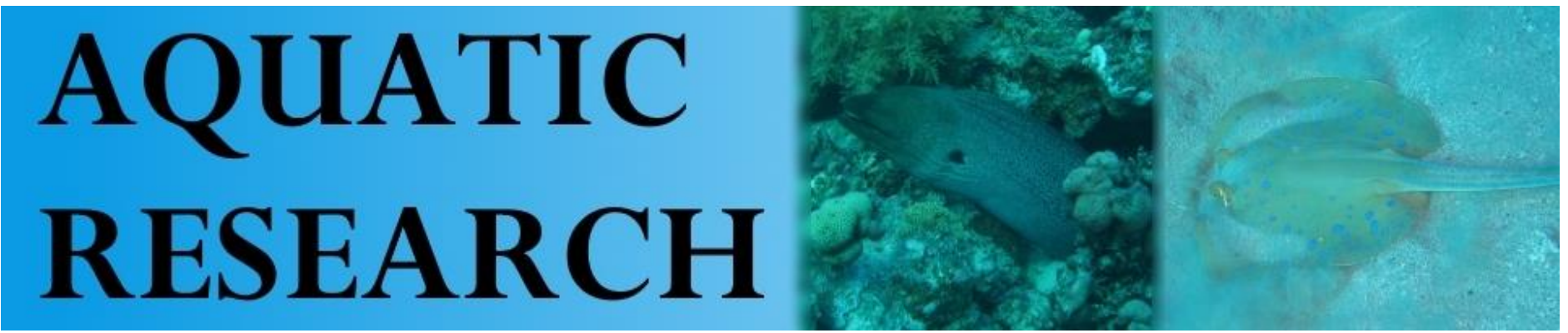

\title{
DETERMINATION OF PARASITIC TRANSMISSIONS BETWEEN JAPANESE FISH (Carassius auratus, GOLDFISH) AND FROGS (Rana ridibunda, Rana viridis)
}

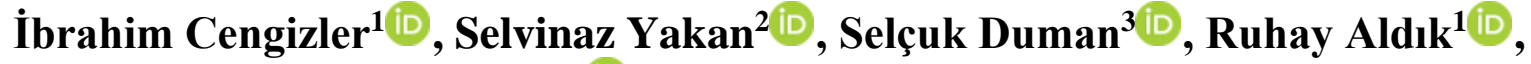 \\ Miray Etyemez Büyükdeveci ${ }^{1}$ (D)
}

\section{Cite this article as:}

Cengizler, İ., Yakan, S., Duman, S., Aldık, R., Etyemez Büyükdeveci, M. (2018). Determination of Parasitic Transmissions Between Japanese Fish (Carassius auratus, Goldfish) and Frogs (Rana ridibunda, Rana viridis). Aquatic Research, 1(4), 140-147. DOI: 10.3153/AR18016

${ }^{1}$ Department of Aquaculture and Fish Diseases, Faculty of Fisheries, University of Cukurova, Adana 01330, Turkey

2 Celal Oruç Animal Production College, Ağrı İbrahim Çeçen University, Turkey

${ }^{3}$ Fisheries Program, Imamoglu Vocational School, University of Cukurova, Adana 01330, Turkey

Submitted: 17.04 .2018

Accepted: 26.06.2018

Published online: 22.07.2018

Correspondence:

İbrahim CENGİZLER

E-mail: icengiz@cu.edu.tr

๑Copyright 2018 by ScientificWebJournals

Available online at

http://aquatres.scientificwebjournals.com

\begin{abstract}
This research conducted ectoparasite scans from frogs (Rana ridibunda, Rana viridis) caught from the same pool as Japanese fish (Carassius auratus) reared in Dr.Nazmi TEKELIOGLU Freshwater Research Station of Cukurova University between April-July 2016 periods. Ectoparasite examinations were performed on a total of 120 fish and 60 frogs a monthly basis April, May and June. For protozoans in stationary preparation; formal acetic acid, Battin's fluid, Carry's fluid, Schaudinn fixative and glycerin were used. Klein's silver impregnation method was used to prepare trichodina preparates. Materials taken by scraping the gills and skin tissues of the fish and the skin tissues of the frog larvaes were examined, and metazoan and protozoan parasites were observed. All Parasites were photographed and identified to the genus level. In all of the study periods, parasites of the genera Dactylogyrus and Thricodina were detected in both fish and frog larvaes. These results indicate that ectoparasite transmission between goldfish and frog larvae was observed.
\end{abstract}

Keywords: Goldfish, Frog larvae, Parasitic transmissions 


\section{Introduction}

The Japanese fish (Carassius auratus) is a fish that is generally used for hobbyist aquaria and pools for visual aesthetics and therefore is important in aquaculture. Aquarium fish cultivated in developed and developing countries are commercially important, and the cultivation of tropical species, which have economical benefits, constitutes the income source of families in these regions. In terms of the aquarium industry, fish are treated in three groups as tropical freshwater fish, tropical marine and brackish water species, and cold water species (Hekimoğlu, 2006). Furthermore, 90\% of these commercial fisheries are provided through aquaculture (Hekimoğlu, 2006; Whittington and Chong, 2007). Freshwater fish comprise nearly half of all aquarium fish. However, 30-35 fish species in the international market have a great importance on trade. One of the most important of these species are the Japanese fish. Cultivation of these species occurs throughout the year in pools where the temperature is warm (Gümüş et al., 2014). Additionally, the true frogs have commercial importance in aquaculture, similar to fish, and frogs are important exports. Ever-declining amphibian populations have led to the need for more studies on the ecology of amphibian species (Alfold and Richards, 1999; Blaustein and Wake, 1990; Houlahan et al., 2000; Meyer et al., 1998; Pechmann and Wilbur, 1994; Wake, 1998). Although monitoring and experimental studies have been attempted, the ecology of these species is not fully understood to date (Green, 1997). Many researchers argue that individual studies must be based on long-term monitoring in order to understand amphibian ecology (Beiswenger, 1986; Brooks, 1991; Freedman and Shackell, 1992; Freda et al., 1991). Frogs are creatures with variable body temperature (poikilotherms) and are not resistant to drought and saline conditions. Frogs hibernate during cold seasons by burying themselves under the ground of lakes and rivers. Amphibians serve as a food source for some freshwater fish, turtles, snakes, birds and mammals. It has also been observed that certain insects use larval frogs as nutrients (Budak and Göçmen, 2005). Through these species interactions, amphibians can transfer disease agents to other creatures. Due to their metamorphosis in their morphological development, their developmental process varies according to species, temperature and other environmental conditions (Başoğlu et al., 1994). In the aquatic environment there is a continuous interaction between vertebrates and invertebrates in terms of infection and parasites. Frequently encountered frogs in aquaculture pools may be hosts for some fish parasites in larval and adult stages. This case causes difficulty in eradication of fish parasites. Similarly, erratic-incidental parasites can be observed in fish. These parasites need to be identified for effective parasite control. A study has shown that Bufomorinus may be infected with 75 helminths, 36 nematodes, 29 digenia, 6 cestodes, 1 monogean, 3 acanthocephala (Barton, 1997). Therefore, it is not desirable to have other vertebrate or invertebrate organisms in aquaculture pools. However, many undesirable vertebrate and invertebrate organisms are present in aquaculture pools as pathogen carriers. If the role of these creatures in contamination is known, the more successful treatments will be. Therefore, this research was conducted with the aim of revealing the ectoparasite interactions between the frog larvae and goldfish observed in the same pools.

\section{Materials and Methods}

This research contains ectoparasite examinations of frogs (Rana ridibunda and Rana viridis) caught from the same pool as Japanese Fish (Carassius auratus) grown in Dr.Nazmi TEKELIOGLU Freshwater Research Station of Cukurova University. The research began in April 2016 when frog larvae emerged. Materials were sampled from frogs larvae (Rana ridibunda and Rana viridis), and Japanese fish (Carassius auratus). The fish and frogs were searched for ectoparasites a monthly basis April, May and June. A total of 120 fish and 60 frogs were examined. Frogs have soft skin and no scales. Therefore, mucus secretion and extremity soles in the skin were specifically scanned. In the samples taken by scraping, X4 and X10 magnifications were first performed, then X40 magnifications for protozoa were performed and the parasites encountered in the field of view were determined and recorded. Fish were examined by fresh preparation using Klein's silver impregnation method in the samples taken by scraping from the gill tissue, mouth, eyes, skin tissue, fins and fin bases (Lom and Dykova, 1992). For protozoans in stationary preparation; formal acetic acid, Battin's fluid, Carry's fluid, Schaudinn fixative and glycerin were used (Forbes et al., 2007; Garcia, 2007; Girginkardeşler and Ok, 2011).Klein's silver impregnation method was used to prepare trichodina preparates (Lom and Dykova, 1992). The frogs were also examined and recorded in the same way as the fish, and pictures of the parasites were taken. For frogs, separation of species and gender were ignored. The water temperature in the pool was also measured and noted. Bauer (1969), Gussev, A. V. (1985), Kabata (1985), Lom (1958) and Lom (1977) were used in the genus-level determination of the parasites observed. 


\section{Results and Discussion}

The pool, where the fish and frogs forming the research material were taken from, can be seen in Figure 1. The average water temperature measured in the pool was measured as $21.4{ }^{\circ} \mathrm{C}$ in April, $24.3{ }^{\circ} \mathrm{C}$ in May and $27.1^{\circ} \mathrm{C}$ in June. Ectoparasites detected during each month are presented below.

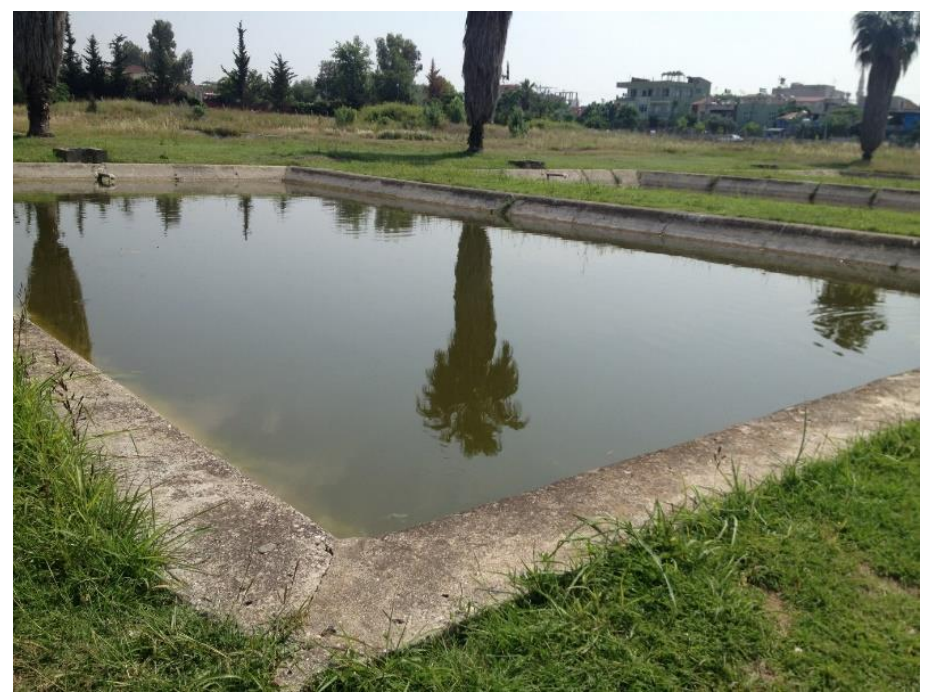

Figure 1. Pool from which research material was taken

April Findings

A total of 40 fish and 20 frogs were included in the screenings performed between April 1 and April 15. The fish and frog larvae used are shown in Figure 2a and 2b.In April, Trichodina sp., Dactylogyrus sp., Chilodenalla sp. parasites were found in both frog larvae and fish. Out of 40 fish, 6 had Trichodina sp. (Figure 3a), 2 had Dactylogyrus sp. (Figure 4a) and 1 had Chilodenalla sp.. From the twenty frogs in the same pool 5 were found to have Trichodina sp. (Figure 3b), 2 Dactylogyrus sp. and 1 Chilodenalla sp. (Figure 4b). These data are presented in Table 1.

\section{May Findings}

In May, goldfish and frog larvae (Figure 5a) were found to have Trichodina sp. and Dactylogyrus sp., however Epistylis sp. parasite was only observed in the frog larvae. From 40 fish, 6 had Trichodina sp., and 2 had Dactylogyrus. In the examinations made on 20 frog larvae in the same pool, 5 had Trichodina sp., 2 had Dactylogyrus and 2 had Epistylis sp. (Figure $5 b$ ). These data are presented in Table 2.

\section{June Findings}

In June, Trichodina sp., Dactylogyrus sp. parasites were found in both goldfish and frog larvae however Gyrodactylus sp. parasites were only found in goldfish. From the 40 fish, 8 had Trichodina sp., 2 had Dactylogyrus sp. and 2 had Gyrodactylus sp. (Figure 6a). Examinations made on 20 frog larvae in the same pool showed that 4 had Trichodina sp. (Figure 6b) and 2 had Dactylogyrus sp.. These data are presented in Table 3.
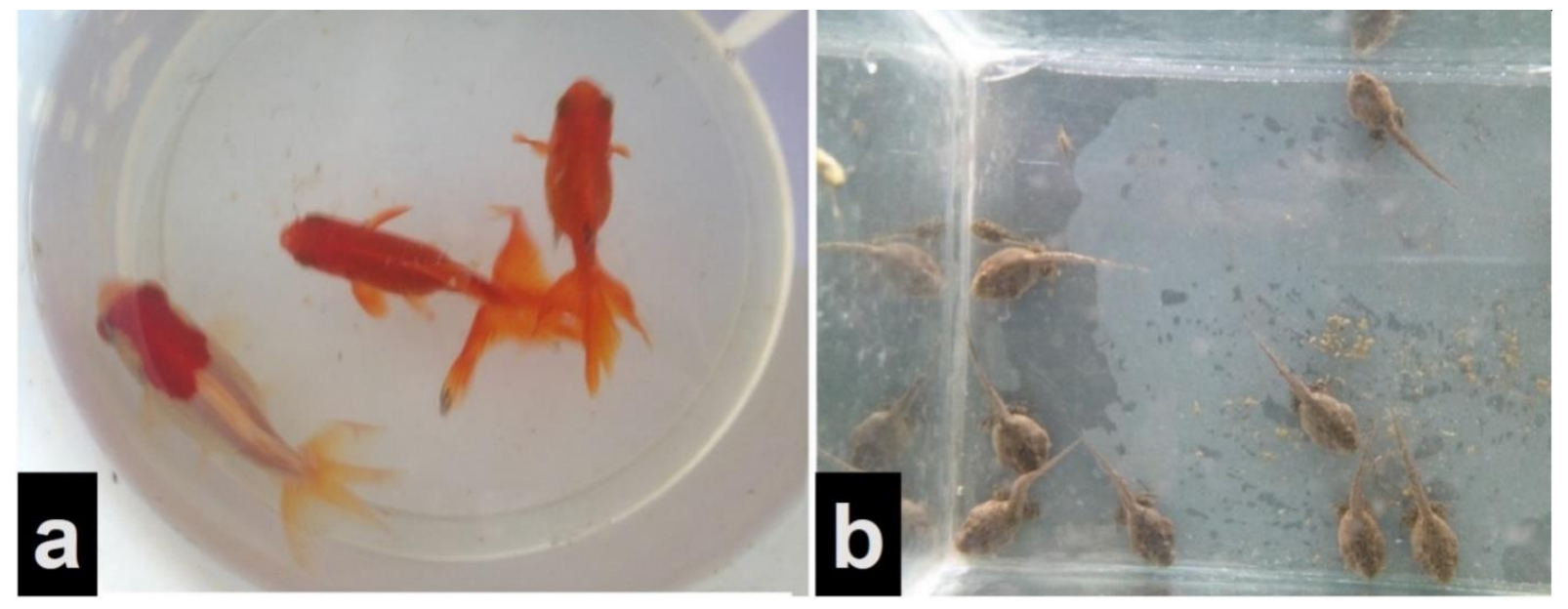

Figure 2. (a), Goldfish used in the research and (b), Frog larvae found in the same pool 
Table 1. Counts of ectoparasites encountered in April

\begin{tabular}{llllll}
\hline Ectoparasite & $\begin{array}{l}\text { Number } \\
\text { of Fish }\end{array}$ & $\begin{array}{l}\text { Number } \\
\text { of Frogs }\end{array}$ & $\begin{array}{l}\text { Fish with } \\
\text { Parasites }\end{array}$ & $\begin{array}{l}\text { Frog larvae with } \\
\text { Parasites }\end{array}$ & F.V.Pa.A. \\
\hline Trichodinasp. & 40 & 20 & 6 & 5 & Fi;4-5 \\
\hline $\begin{array}{l}\text { Dactylogyrus } \\
\text { sp. }\end{array}$ & 40 & 20 & 2 & 2 & Fr;1-3 \\
\hline $\begin{array}{l}\text { Chilodenallasp. } \\
\text { Fi; } ; 1-2\end{array}$ \\
\hline
\end{tabular}

F.V.Pa.A.: Total parasites detected in a field of vision (X100). Fi: fish, Fr: frog larvae

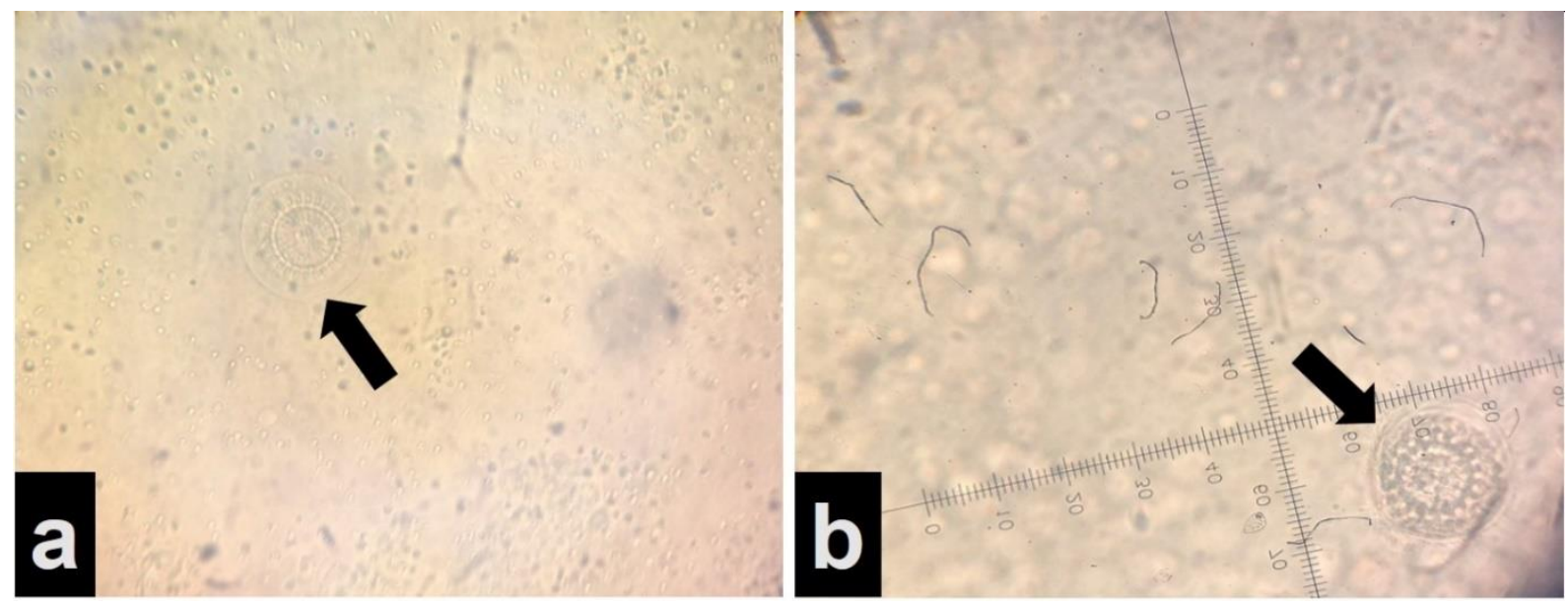

Figure 3. (a) Trichodina sp. From the skin of goldfish and (b) Frog larvae (bottom) (X40)
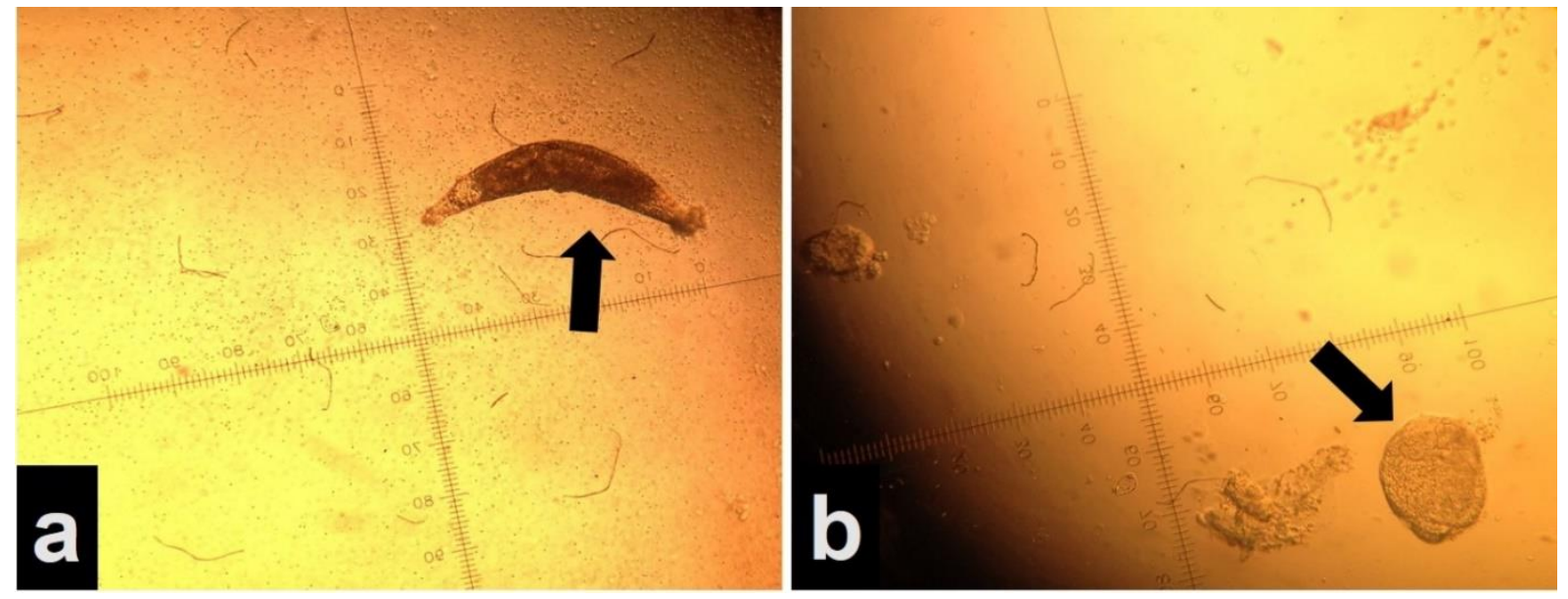

Figure 4. (a) Dactylogyrus sp. in the goldfish (X40) and (b), Chilodanella sp. in the frog larvae (X40) 

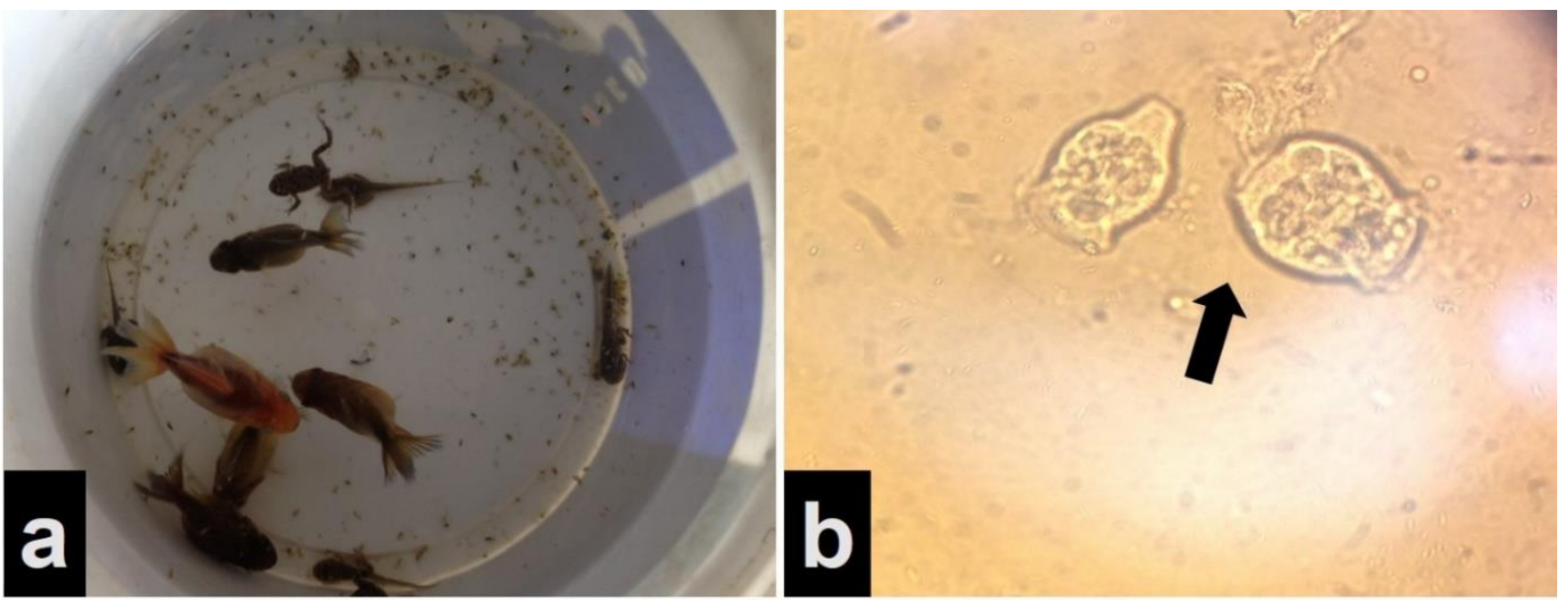

Figure 5. (a) Goldfish and frog larvae samples of the research material. (b) Epistylis sp. found in frog larvae in the same pool (X40).

Table 2. Counts of ectoparasites encountered in May

\begin{tabular}{llllll}
\hline Ectoparasite & $\begin{array}{l}\text { Number of } \\
\text { Fish }\end{array}$ & $\begin{array}{l}\text { Number of } \\
\text { Frogs }\end{array}$ & $\begin{array}{l}\text { Fish with } \\
\text { Parasites }\end{array}$ & $\begin{array}{l}\text { Frogs with } \\
\text { Parasites }\end{array}$ & F.V.Pa.A. \\
\hline Trichodinasp. & 40 & 20 & 6 & 5 & $\mathrm{Fi} ; 4-5$ \\
\hline Dactylogyrus sp. & 40 & 20 & 2 & 2 & $\mathrm{Fr} ; 1-3$ \\
\hline Epistylissp. & 40 & 20 & & 2 & $\mathrm{Fi} ; 1-2$ \\
\hline
\end{tabular}

F.V.Pa.A.: Total parasites detected in a field of vision (X100). Fi: fish, Fr: frog

Table 3. Counts of ectoparasites encountered in June

\begin{tabular}{llllll}
\hline Ectoparasite & $\begin{array}{l}\text { Number of } \\
\text { Fish }\end{array}$ & $\begin{array}{l}\text { Number of } \\
\text { Frogs }\end{array}$ & $\begin{array}{l}\text { Fish with } \\
\text { Parasites }\end{array}$ & $\begin{array}{l}\text { Frogs with } \\
\text { Parasites }\end{array}$ & F.V.Pa.A. \\
\hline Trichodinasp. & 40 & 20 & 8 & 4 & $\mathrm{Fi} ; 4-5$ \\
\hline Dactylogyrus sp. & 40 & 20 & 2 & 2 & $\mathrm{Fr} ; 1-3$ \\
\hline Gyrodactylus sp. & 40 & 20 & 2 & $\mathrm{Fi} ; 1-2$ \\
\hline
\end{tabular}

F.V.Pa.A.: Total parasites detected in a field of vision (X100). Fi: fish, Fr: frog larvae 


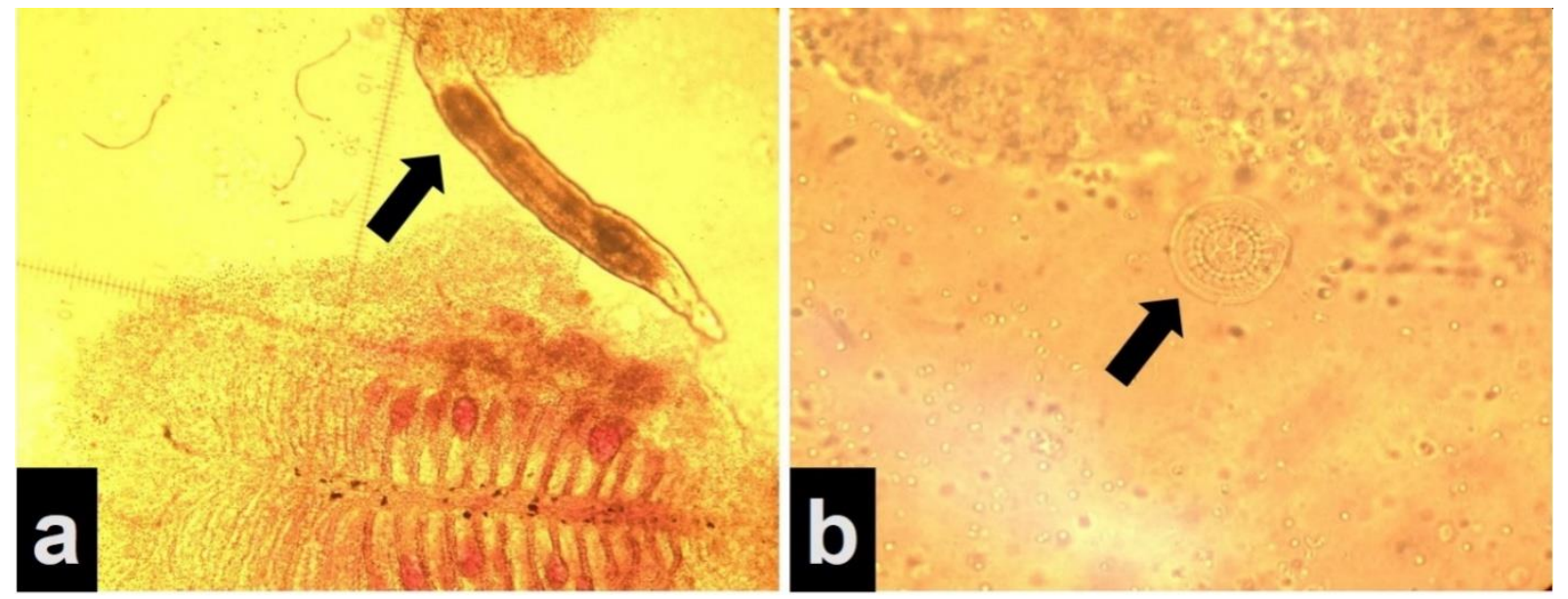

Figure 6. (a) Gyrodactylus sp. found in the fish gill (X40) and (b) Trichodinasp. found in the frog (X40).

Vertebrate and invertebrate animals co-occur in aquatic environments. While this coexistence is often harmless, it can become harmful at times when pathogens are transferred. Especially in aquaculture areas, frogs and fish may coexist together. However, there is an ectoparasitic interaction between frogs and fish. Prior research discovered 9 Diegena, 4 Nematoda, 2 Acenthocephala and 1 Hirudinea in Rana ridibunda (Yıldirımhan et al., 2005). In studies carried out by Y1ldırımhan et al., (2005) to investigate the metazoan parasites of marsh frogs (Rana ridibunda pallas 1771; Anura) collected from the different regions of Turkey, juvenile individuals of Hiruda medicanalis from the Annelida filumu, Hirudinea class were found on the backs and between the legs of the frogs. Kir et al., (2001) did not encounter any Hirudinae in Rana ridibunda pallas 1771; Anura: Radinae frogs they caught from Eğirdir lake. Most of these parasites can also infect fishes and survive. Infestation caused by protozoan parasites play an important role in fish diseases (Cengizler, 2000; Schäperclaus, 1991). There are many studies on protozoan parasites in fishes. Studies on parasites observed in some aquarium fish species by Doganay, (1994) revealed that $26.6 \%$ had Trichodina sp. and $33 \%$ had the Chilodonella cyprini parasite. Lom and Dykova (1992), reported that Oodinium pillularis grows in tropical aquarium fish under favourable environmental conditions and causes deaths in a short period of time. Koyuncu and Cengizler (2002), detected protozoan ectoparasites living in the skin, fin and gill tissues of some aquarium fishes (Poecilia reticulata, Poecilia latipinna, Xiphophorus helleri, Xiphophorus maculatus) cultivated in the Mersin region. 950 fishes were examined between January 2001 and January 2002 for their seasonal distribution and 720 of them were found to be infested with protozoan parasites. In our research, ectoparasites found in frogs and fishes taken from the same pool were identified to the genus level. In our research, in which we conducted an ectoparasitic study in fish and frogs according to months, we discovered that Trichodina sp., Dactylogyrus sp. and Chilodenalla sp. parasites were living in both frog larvae and goldfish in April. However, in May, Trichodina sp. and Dactylogyrus sp. parasites were detected in frog larvae, as well as in goldfish, and the Epistylis sp. parasite was only found in frog larvae. In June, Trichodina sp., Dactylogyrus sp., parasites were found in both goldfish and frog larvae and Gyrodactylus sp. parasites were only found in goldfish samples. Our findings differ from the results of other researchers in terms of ectoparasites we detected in frog larvae (Yıldırımhan et al., 2005; Kir et al., 2001, Doganay, 1994). Four new parasite species were found in frogs, Trichodina sp., Dactylogyrus sp., Chilodenalla sp. and Epistylis sp.. Moreover, ectoparasites species Trichodina sp., Dactylogyrus sp., Chilodenalla sp., and Gyrodactylussp. have been identified in fish. In our findings Trichodina sp. encounters are consistent with the findings of Doğanay et al., (1983).In our study, parasites of the genus Dactylogyrus and Thricodina were found in both fish and frogs taken from the same pool during all examination periods. The presence of frogs in the aquaculture environment will usually carry out parasitic interactions. Therefore, frogs need to be removed from the aquaculture environment. It has been reported that in carp under one year old, if there is an average of 5 to 25 parasites treatment should be undertaken (Schaperclaus, 1991). Thus, the number of parasites observed in each field of view were presented in this study. However, according to these findings, there is no infestation that requires treatment. According to our results, the occurrence of Dactylogyrus 
and Thricodina parasites of the same species in both frog larvae and goldfish is an example of parasite interactions.

\section{Conclusions}

Consequently, keeping the frogs away from aquaculture pools may prevent infectious and infestation sources from infecting the fishes. Rana ridibunda and Rana viridis type frogs, which are also used as food, have economic value, and more comprehensive parasitological studies on human health impacts are warranted.

\section{References}

Alford, R. A., Richards, S. J. (1999). Global amphibian declines: a problem in applied ecology. Annual review of Ecology and Systematics, 30(1), 133-165.

Anonim, (2017). Amazing species. http://www.iucnredlist.org/ (accessed, 01.04.2017).

Başoğlu, M., Özeti, N., Yılmaz, İ. (1994). Türkiye amfibileri. Ege Üniversitesi Fen Fakültesi Kitaplar Serisi No: 151. 1-221. ISBN: 975-483-658-2

Bauer, O.N. (1969). Key to the Parasites of Freshwater Fauna of The USSR, Vol.1, Leningrad, p. 428.

Barton, D. P. (1997). Introduced animals and their parasites: The cane toad, Bufo marinus, in Australia. Austral Ecology, 22(3), 316-324.

Blaustein, A. R., Wake, D. B. (1990). Declining amphibian populations: a global phenomenon? Trends in Ecology Evolution, 5, 203-204.

Beiswenger, R. E. (1986). An endangered species, the Wyoming toad Bufo hemiophrys baxteri the importance of an early warning system. Biological conservation, 37(1), 59-71.

Brooks, R. J. (1991). Monitoring wild life populations in long-term studies. Canadian Wild Service Occasion Papers, 76, 94-97.

Budak, A., Göçmen, B. (2005). Herpetoloji. Ege Üniversitesi Fen Fakültesi Kitaplar Serisi, No. 194, Ege Üniversitesi Basimevi, Bornova-Izmir, 226 s. ISBN: 975-483$658-2$
Gussev, A. V. (1985). Key to parasites of the freshwater fishes of the USSR, Metazoon parasites Vol. 2, Publ. House Nauka, Leningrad, 424.

Cengizler, İ. (2000). Lecture Book of Fish Diseases. Çukurova University. Su Ürünleri Yayınları, Yayın No:7, 136, Adana. ISBN: 975-487-080-2

Doganay, A. (1994). A record of Hysterothylacium aduncum (Rudolphi, 1802) in cod-fish (Gadus sp.) from Black Sea. Veterinary Journal of Ankara University, 41, 208-217.

Freedman, B., Shackell, N. L. (1992). Amphibians in the context of a National Environmental Monitoring Program. Occasional paper. Canadian Wildlife Service. Ottawa On Occas. Pap. Can. Wildl. Serv. ISBN: 09634030-1-X

Freda, J., Sadinski, W. J., Dunson, W. A. (1991). Long term monitoring of amphibian Populations with respect to the effects of acidic deposition. Water, Air, and Soil Pollution, 55(3-4), 445-462.

Forbes, B. A., Sahm, D. F., Weissfeld, A. S. (2007). Laboratory methods for diagnosis of parasitic infections. Bailey \& Scott's Diagnostic Microbiology. 12th ed. St Louis; Mosby, 595-598. ISBN: 0-323-04780-7

Garcia, L. S. (2007). Calibration of microscope with an ocular micrometer. Clinical Microbiology procedures handbook. 2nd ed. update, ASM Press, Washington DC. ISBN: 10-98765-4321

Girginkardeşler, N., Üz, O. (2011). Kalıcı boyalı yaymalar. Parazitolojide Laboratuvar.Türkiye Parazitoloji Derneği Yayınları, İzmir. ISBN: 987-0-12-4077

Gümüş, E., Kanyılmaz, M., Gülle, İ., Sevgili, H. (2014). Structural and technical analysis of ornamental fish farms in Antalya region: II. Technical features and marketing considerations. ISNB: 13083961

Green, D. M. (1997). Amphibians in Decline, Canadian Studies of a Global Problem, Herpetological Conservation. ISBN: 0916984400

Hekimoğlu, M. A. (2006). The situation of aquarium sector in the world and Turkey. Ege Journal of Fisheries and Aquatic Sciences, 23(2), 237-241. 
Houlahan, J. E., Findlay, C. S., Schmidt, B. R., Meyer, A. H., Kuzmin, S. L. (2000). Quantitative evidence for global amphibian population declines. Nature, 404 (6779), 752.

Kabata, Z. (1985). Parasites and diseases of fish cultured in the tropics. Taylor \& Francis Ltd., Philedelphia, Pensylvania, 318 pp. ISBN: 0850662850

Kır, İ., Yıldırım, M. Z., Becer, A., İkiz, R. (2001). Eğirdir Gölü Ova Kurbağalarının (Rana ridibunda Palas 1771; Anura: Ranidae) beslenmesi ve Parazitleri. Türkiye Parazitoloji Dergisi, 25(1), 83-87.

Koyuncu, E., Cengizler, İ. (2002). Protozoan ektoparasites occuring in some of the aquarium fishes (Poecilidae) raised in Mersin District. Ege Journal of Fisheries and Aquatic Sciences, 19(3), 293-301.

Lom, J. (1958). A contribution to the systematics and morphology of endoparasitic trichodinids from amphibians, with a proposal of uniform specific characteristics. Journal of Eukaryotic Microbiology, 5(4), 251-263.

Lom, J. (1977). Ciliates of the genera Trichodinella, Tripartiella and Paratrichodina (Peritricha, Mobilina) invading fish gills. Folia Parasitologica, 24, 193-210.

Lom, J., Dykova, I. (1992). Protozoan Parasites of Fishes. Developments in Aquaculture and Fisheries Science, 26, 160-235.
Meyer, A. H., Schmidt, B. R., Grossenbacher, K. (1998). Analysis of three amphibian Populations with quarter century long time series. Proceedings of the Royal Society of London B: Biological Sciences, 265(1395), 523-528.

Pechmann, J. H., Wilbur, H. M. (1994). Putting declining amphibian populations in perspective: natural fluctuations and human impacts. Herpetologica, 50(1), 65-84.

Schäperclaus, W. (1991). Diseases caused by ciliates. Fish diseases. Amerind Publishing, New Delhi, 702-725. ISBN: 0-85199-015

Wake, D. B. (1998). Action on amphibians. Trends in Ecology and Evolution, 13(10), 379-380.

Whittington, R. J., Chong, R. (2007). Global trade in ornamental fish from an Australian perspective: the case for revised import risk analysis and management strategies. Preventive Veterinary Medicine, 81(1-3), 92-116.

Yildirimhan, H. S., Karadenız, E., Gürkan, E., Koyun, M. (2005). Metazoon parasites of the marshfrog (Rana ridibunda pallas 1771; Anura) collected from the different regions in Turkey. Turkiye Parazitolojii Dergisi, 29(2), 135-139. 